\title{
Ellipsis
}

Volume 43

Article 21

2016

\section{The Neighbor}

Caitlin Hand

University of New Orleans, New Orleans

Follow this and additional works at: https://scholarworks.uno.edu/ellipsis

\section{Recommended Citation}

Hand, Caitlin (2016) "The Neighbor," Ellipsis: Vol. 43 , Article 21.

DOI: https://doi.org/10.46428/ejail.43.21

Available at: https://scholarworks.uno.edu/ellipsis/vol43/iss1/21

This Fiction is brought to you for free and open access by the Department of English and Foreign Languages at ScholarWorks@UNO. It has been accepted for inclusion in Ellipsis by an authorized editor of ScholarWorks@UNO.

For more information, please contact scholarworks@uno.edu. 


\title{
The Neighbor
}

\author{
Caitlin Hand
}

They moved in on a Wednesday. Their house was bigger than mine, two stories, four bedrooms, red brick, a garden that was once pristine but now turning shabby. I wondered if our new neighbors would keep up with it, if the shrubs and pink flowers would become their pride and joy as it was the Downy's.

I looked out the window a minute longer, then quickly let the shade close when I heard my dad come out of his room and into the kitchen.

"Morning," he said, walking over to the coffee pot and pouring himself a cup.

"Good morning," I said, returning to my spot at the table.

Dad must have taken a look out the window, too, because he said, "So our new neighbors are moving in."

I smothered my bagel with peanut butter and took a bite. "Seems like it," I said after I had swallowed.

"They look friendly."

My dad thought everyone looked friendly. The year before, a stray dog had wandered into our yard and he thought the little dog looked super friendly. The dog wound up biting him on the hand, requiring stitches. He still had a scar right under his thumb.

I took a sip of my coffee and didn't respond.

I heard the toaster pop, and then my dad sat down at the table with his toast and coffee.

"What are you up to today?" he asked as he buttered his bread.

"I have some homework due tonight, and I should probably clean my bathroom."

"You know," he started after taking a bite, "if you wanted to take classes on campus, I could lend you the car a few days a week."

My heart sped up instantly at the thought and my stomach began to churn.

"No," I said. It came out sharper than I intended, so I added, "I like my online classes."

His eyebrows drew together, looking worried. He always looked worried. Ever since my mom left three years prior, he was constantly concerned with everything about me - my schoolwork, my social life, my eating habits. I understood, and I was understanding more every day, because I worried over him, too. But sometimes his worry felt displaced and his ideas on how to "help" me were in no way helpful.

He shrugged. "If you're sure."

"I am." I stared at my bagel, letting my heart come down. I suddenly wasn't hungry anymore, and the partially eaten bagel looked pathetic and 
disgusting sitting on my plate. Even my coffee, light brown and turning cold, made me feel slightly queasy.

Dad finished eating while I stared off at our tile floor, getting lost somewhere else.

My dad stood up and asked, "You finished?"

I nodded and scratched at my arm. It was a new habit that was only recently brought to my attention by my therapist. I had been talking to the same woman for two years, and she noticed everything. It was both unnerving and comforting to be watched so closely by someone that wasn't my father.

After my dad loaded the dishes in the sink, he shrugged on his jacket, pocketed his wallet, and grabbed his keys off the counter. He stared at me for a moment, and I pretended not to notice.

"You gonna be okay?"

I slowly turned my head to stare at him, giving a slow nod. His bright blue eyes were childlike, both sweet and penetrating. I quickly looked away.

He walked over, bent down, and kissed the top of my head.

"Love you, too," I mumbled, pulling my sweatshirt sleeves over my hands.

As he made his way out of the house, he said, "I'll call you later. Maybe you can come meet me for lunch."

"Sure," I said.

But we both knew I wouldn't. Because I never did. I left the house as little as possible. The last time I left was the week before because I needed tampons and it couldn't have waited until my dad got home. He meant well, and was hopeful, but I think my dad knew, deep down, it wouldn't happen.

Once I heard the garage close, I stood up and went back to the window. I did feel slightly creepy staring out at them, but I actually liked people. They just made me nervous. Everything made me nervous. Apparently, that was why I was in therapy - to find out why. I would never admit it, but those weekly appointments weren't completely useless.

Looking at the two people unloading boxes and mattresses, I wanted to go outside and introduce myself. I wanted to meet them, talk with them. But this paralyzing fear that made my heart rate spike and my palms tingle and my nose itch kept me from even imagining the scenario where I walk out my front door and over to them. The desire to not throw up kept me inside, and it even pushed me to take a step away from the window.

There was this battle between what I wanted to do-what I wished I could do - and the thing inside me that kept me from being able to do it. I wished I was someone else, something else, somehow different, somehow normal. Knowing I wasn't and having little hope I ever would be made me sick in a way the nervousness never could.

I continued watching them as they brought box after box inside. I noticed three mattresses, but saw only two people. A woman, probably my dad's age, and a guy, maybe a little older than myself. They were both tall and blond, graceful as they carried in their items from the moving truck and cars. 
As I watched them, something in the corner of my eye caught my attention. It was another one of my neighbors, dressed in bright yellow athletic clothes, pushing her large, fancy stroller. She turned the corner and stopped in front of their driveway, waving to the newcomers.

I knew her. She was in her thirties and talkative, bright and opinionated, the opposite of a homebody but a dedicated stay-at-home mom. She could talk to anyone, no matter how well she knew them, even if she knew them not at all. She talked to anyone and everyone with ease and pleasure. I didn't want to be her. I didn't. But I wanted the ability to do what she did.

I watched them talk for a little longer, but she didn't seem to be letting up anytime soon. Both of them stayed and talked with the bright neighbor, but before long he went back to moving his stuff inside the house. I stopped watching after that, a storm of inadequacy and curiosity that would never be fulfilled whirling within me.

I paused before walking away from the window, and decided to pull the shades open.

I got my laptop and situated myself at the kitchen table, opening up my online courses. I worked through my homework for a few hours, taking a coffee break and a bathroom break. I peeked out the window every once in a while, taking notice of different cars coming and going from the house across the street, but all I could think of was the piece of paper in my pocket.

That slip of pink paper sat in my pocket, as it had been doing since the previous Thursday when Sarah gave it to me. It was a reminder, a fear, an impossibility, all wrapped into the tiny word Sarah called it: a task. She gave them to me sporadically, whenever she felt I was ready for something. The first one was four months into therapy, and she had me offer to run an errand for my dad. Even if he said no, I had to offer. And I did. My voice shook when I asked, just the idea of going to the grocery store making my mouth dry. I did it, though, and my dad declined. I remembered my relief being greater than the fear. Per Sarah's instructions, I had to write it all down, what I felt before, during, and after.

The following Thursday I went to my next session, with my journal, and we talked it out. I was surprised at the anger that came out as I talked about it. I cried and I yelled, screaming at her that I wasn't ready and I didn't understand how being forced to do something like that was helping. She calmly sat and listened, and when I cooled off, I sat back down and listened to her to explain. She was the expert, she saw things I didn't, and she felt I was ready.

I told her I felt like I failed, like I didn't do anything productive.

"You completed the task," she said. "All it said on that piece of paper was to offer to run an errand, and you did. Nothing more. You broke through that fear, as I knew you could."

After that I constantly braced myself for more tasks, not knowing when the next one would come or what it would be. Three months later and that next task was given to me, as it sat in my pocket that very moment.

On the paper, in all caps, blocky letters that took up almost the entire surface of the notepad paper, it read: Say "hi" to a stranger. 
It was my own fault, the task. I mentioned the new neighbors to Sarah when the house first sold, and then again later I brought it up. It shouldn't have surprised me that she read something of it, made something of it.

While technically it didn't have to be the new neighbors to complete the task, they seemed like my best bet, especially considering I had one day left before my next meeting with Sarah. She'd give me more time, I knew that, but she'd be disappointed. I'd see in the line between her eyebrows. A part of me wanted to prove something to her, as well. I liked Sarah. Most of the time, anyway. I wanted to make her proud, show her I was improving, and show her I wasn't wasting her time. I wanted to show my dad I wasn't wasting his money. Show myself I wasn't wasting my life.

Another, stronger part of me felt I needed more time, though. This was insane, I'd think over and over again. There was no way Sarah could tell me to do something like this and expect me to be able to just do it. There was no absolute way.

These tasks, all two of them, instilled in me a fear I didn't feel I could handle, but I wanted to handle them. I wanted to at least pretend I could handle them.

The day passed and not much was happening. They were in and out all day. The woman was inside a lot, while he took over the garage. I needed a reason to go outside, and all I could think of was to get the mail. But I couldn't get up enough bravado to even go near my front door. Instead, I remained in the kitchen. I made more coffee - which, in hind sight, probably wasn't a good idea considering my already shaky demeanor. I made lunch. I finished up my homework. I dusted the living room and cleaned my bathroom. Nothing took my mind away from the neighbors, the task. I'd get into a groove of cleaning, then my mind would instantly revert back to what I needed to do. What I wanted to do, but couldn't.

I made it to the door once. I felt okay for a split second. Then, as I went to turn the knob, I realized the truth. I couldn't do it. I shouldn't do it, I told myself. They were busy, trying to get moved in and settled. I remembered moving into our house. It was a nightmare. The last thing my parents would have wanted was some strange girl coming up and bothering them. I had a feeling my new neighbors wouldn't want that, either. So with a burning face, I plopped myself on the couch and stayed there, my mind bouncing and turning without signs of letting up.

Then the doorbell rang. A chime that blared in my ears, making me jump out of my internal neurosis. I froze and just stared at the hallway leading to the front door, thinking maybe I had heard wrong. Then the doorbell rang again, followed by a series of knocks. I slowly got up, dragging my sock feet across the floor. I had a flash of panic, a brief moment of imagining walking away, locking myself in my room, and letting it be.

I was still human, though, and curious. We really didn't get a lot of visitors, and it was it the middle of the day. I immediately thought it might be the new neighbors, making my job a whole lot easier. I couldn't decide if I was more terrified or grateful at the prospect. 
Standing in front of the door, I looked through the peephole, and there stood not the new people, but my bright yellow neighbor, Karen. She knocked again on the door, making me jump.

"Hello," she called cheerfully through the door. "Melody, honey, you home?"

Taking a deep breath, I turned the knob, opening the door but barely.

"Hi," I started to say, but my voice sounded rough. I cleared my throat, tried again.

"Hey, honey," she said, pushing her stroller back and forth. The shade on the stroller was drawn so I couldn't see inside. "Beautiful day, right?"

I nodded, my hand gripping the side of the door.

She smiled, then said, "How are you doing?"

"I'm okay." I paused, then asked, "Did you need something?"

Her eyes got big and she nodded, causing her bright red hair to bounce in its ponytail. "Yes, yes, sorry." She pointed her thumb over her shoulder. "Your gate's open. I peeked but didn't see anyone in the backyard, so I thought I'd come see who was home and let ya know."

“Oh, I'll, um, go close it right now," I said. Then I tacked on, “Thank you."

"You're very welcome."

She stopped talking, but she didn't leave. She just kept pushing the stroller and looking at me.

I was trying to work out a way to ask if she needed anything else without sounding rude, but I couldn't think of anything. Luckily, she spoke up soon after.

"So I don't see you much anymore. Things are okay? How's your daddy?"

Nodding, I said, "Things are good. He's good."

I knew Karen probably wanted more, but I was inept and could not get my brain and mouth to form coherence, and it was out of the question in getting them to work together. It was a lost cause.

"Well, that is great to hear."

"Mmm," I mumbled. Then I grabbed my shoes that were sitting by the front door, tugged them on, and stepped outside.

I don't know why I thought she would go on her way, but I did. So I was surprised when she followed me around my house to the back, but I shouldn't have been. I stared down as I walked around the house, Karen right my side, pushing her stroller.

"So have you met the new neighbors?" she asked. When I looked over to her, her neck was turned, staring at the house, or the big moving truck, or the boxes piled up inside the garage. Maybe she was staring at the large mattress just waiting to be brought inside. Even from where I stood, I could hear the country music spilling from somewhere in the garage.

"Not yet," I said, biting my lip.

We made it to the fence and I saw it was wide open, the large wooden door completely up against the side of the fence. I started pulling it out to close it, but of course it got caught in the still wet grass. 
"They're really very sweet," Karen said as I tugged on the door, my knuckles straining, my strength no match for the thick, muddy ground. "An older couple with a son in college. I think the dad's sick or something, from the way they were talking."

I paused on the fence and looked to find her staring at me.

"I believe he's your age. Real nice. Cute, too." She threw me a wink.

My face warmed. Looking away, I resumed my tugging.

"Do you need help with that?" Karen asked.

I shook my head, but she either didn't see or ignored it.

"I'm sure the new boy would be happy to help. He was doing all the heavy lifting for his mom, it seemed. I'm sure this would be no trouble for him."

"I'm good," I said, but even I heard the slight strain in my voice.

"If you're sure." She was quiet for a minute, then, "Oh, there he is now. I don't mind running over and asking him for you?"

The piece of paper, the task, Sarah, and my nerves were all on the forefront of my mind as she asked this. It could be easy. Well, easier. Karen could get him to come over, he could tug the fence, I could say one, maybe two, words, and it would be over. Task would then be completed. I was aware of this, and yet my mouth was out of sync with my mind.

"No," I said, "I've got it." And a moment later, I had it. The gate swung closed and I locked it up, making sure it was secure.

Relief and disappointment rested on my shoulders. It could have been easier, having help from Karen. It could have been over; I would have had a full story to tell Sarah. But my opportunity was gone and the whole endeavor was back on my shoulders, completely on me. Whether I realized it at that moment or not, it was a good thing, having the sole responsibility of the task, not leaving any of it to anybody else. It was the main purpose of Sarah's assignment, I'd later realize. Putting myself out there, doing things on my own. There were reasons behind the assignments, and using Karen to do the hard part, taking the initiative, wouldn't have truly helped me at all.

"Our gate does the same thing," she said, shaking her head. "Anyway, I hope you introduce yourself soon. They really do seem very sweet. Plus we wouldn't want the neighborhood to come across as unwelcoming."

"Yeah, of course," I said. "Um, I've got some things to do, but, uh, I'm sure I'll go over soon."

"Good." She smiled then, showing her shiny white teeth, and pulled down her sunglasses from the top of her head. "Well, we should get going. Tell your dad I say 'hi.' Have a good day, sweetie!" she called as she made her way off my lawn and onto the street, heading in the direction of her house.

I stared after her, watching her ponytail bounce, until I heard a door shut. Looking over to the new neighbor's house, I saw the guy coming out. I couldn't do it. I could feel myself locking up as my mind screamed at me to walk up closer, wave, say something. But I couldn't. Instead, I walked straight back inside my house. Peeking out the window once I was inside, I saw him get in the small silver car parked in the driveway and I watched as he pulled out. 
I didn't understand this fear of new people, people in general. Sarah said it was a product of my mother leaving, but I could never connect the two. I never saw the link. All I could connect was the subtle change from a shy person to this extreme fear of new things, new people, the unknown. I could talk to Karenbarely - because I've known her since I was six. But I hated running errands for fear of crowds. The idea of starting classes at a university left my stomach twisting and turning with knots. It wasn't surprising that something so simple was so impossible for me to do.

I stopped looking out the window, breathed, and let my shoulders relax. I then promptly crashed on the couch, bellyflop style, and buried my head in the pillows. I wanted to scream. I wanted to cry. But I couldn't and it felt like this brick in me - a brick of frustration and sadness that overwhelmed and embarrassed me. I was sick of it, so tired of it, and it was becoming physical. My inability to act like a functioning human being was becoming a physical exhaustion that swept over my body, drowning me, leaving me unable to see the surface. All I could see was what I wasn't, and what I probably never would be.

As I wallowed in self-disgust, I felt my phone buzz in my pocket. Pulling it out, I saw it was my dad calling. With a sigh, I answered. "Hey, Dad."

"Hey, sweetie," he said. In the background I could hear him typing loudly on his computer. I imagined his phone pressed between his ear and shoulder. "I was thinking pizza for lunch. Maybe Johnny's? They have that salad bar I think you'd like."

"Um," I said, still staring at the fan. "I don't think so."

"Okay," he sighed, "I'll do hamburgers."

"No, I don't think I can come," I said, feeling the need to look away from the spinning fan.

"Oh." That one word, so simple, but so heavy coming from him. It was filled with so much. "Well, that stinks."

"Yeah, I'm sorry. This assignment I have due is a lot harder than I thought. So I should stay home and finish it."

"Right," he said. "Of course." I listened for a moment, and noticed I didn't hear his typing anymore.

"I'm sorry," I whispered.

"Me, too," he said. Simple, but once again loaded. "I'll bring something home for dinner."

We clicked off and I stayed on the couch for a while, trying to bury the guilt and shame and annoyance deep, deep down. At some point, I flipped over onto my back, bringing the pillow to my chest and hugging it tight. I stared at the ceiling fan, watching it go round and round, wishing my mind would go blank, that my thoughts could easily be wiped clean, cut through by the blades of the fan as seamlessly they did the air. If only it was that easy.

It wasn't, though. My thoughts couldn't be wiped away; my nerves and my fears couldn't be cured instantly, magically, through sessions with a therapist and assignments meant to break me out of my bubble of fear. I knew this, and yet I still wished they would. I didn't want to be whatever I was anymore. And at eighteen, a time when I was supposed to be finding myself, not losing myself 
completely to my own incapability, I was retreating and stuck in a lightless hole, wanting and failing to see a telling sign that things would change. I felt stuck. I was stuck. My insides were daily, constantly, trying to come out. This person I desperately wanted to be, or pretend to be, trying to burrow out of this brittle exterior of a body incapacitated.

Frustration and anger was, honestly, always in me, boiling slowly, preparing itself. But I was more aware of it then than I ever had been before. I felt it, like a physicality running through me, severe and hot. I was angry at myself and my dad and Sarah and life, a higher being that was maybe in control and failing to fix me, failing to give me answers. I would later find out who I was really angry at. But at that moment, as I lay on the couch, wallowing in selfloathing, was blind.

But there was a part of me that knew I wanted to be nothing like her. Her fear drove her away. Her ignorance and selfishness, stemming from fear of something I'd never know, made her leave. And greater than the fear I had of everything was the fear that I'd become like her, allowing myself to be driven by a controllable factor.

With a nausea rumbling with the idea of being controlled by anything but myself got me up off the couch, made my feet move to the front door and out. I stood on my porch, taking a deep breath and looking at the house. No one was outside, and the car the guy had driven off in was still gone.

I waited, and the outside remained empty. Off in the distance, I heard a lawn mower's engine and, faintly, country music still coming from the house across the street. The wind picked up, giving a chill, and I wrapped my arms around myself.

I waited just a little longer, more relieved than I wanted to actually admit. I'd be okay if this didn't happen. I really would. My dad and Sarah would disagree, but I knew I'd be just fine. The opportunity was gone, once again, and I'd be okay. It was for the best, I told myself.

But then I heard it. The white door opened and closed quickly. I looked over, surprised to see the guy walking out. I stepped forward, off my porch and onto the walkway, unsure where the act came from. I lifted my foot to step forward once more, but instead I bit the inside of my cheek and walked to the mailbox, my heart thumping painfully. I saw that the guy was hauling a trash bag out to the curb.

As I pulled out the mail, I looked over and found him looking my way. I froze, completely stopped what I had been doing, as he smiled and waved.

"Hey," he called.

I thawed slightly, and opened my mouth to speak, but nothing came out. So I simply raised my heavy hand and waved, giving what I thought was a smile. 